\title{
Implications of low food availability on resource partitioning among three species of Cichlidae (Pisces: Perciformes) in a Brazilian semi-arid reservoir
}

Implicaçôes da baixa disponibilidade de itens alimentares na partição de recursos entre três espécies de Cichlidae (Pisces: Perciformes) em açude do semiárido brasileiro

Bruno Renaly Souza Figueiredo ${ }^{1}$, Gabrielle Joanne Medeiros Araujo²,

Márcio Joaquim da Silva ${ }^{1}$ and Elvio Sergio Figueredo Medeiros ${ }^{1}$

${ }^{1}$ Grupo Ecologia de Rios do Semiárido, Universidade Estadual da Paraíba - UEPB,

Rua Horácio Trajano de Oliveira, s/n, Cristo Redentor, CEP 58020-540, João Pessoa, PB, Brazil e-mail: figueiredo.biologo@gmail.com; silva.marcio.j@gmail.com; elviomedeiros@uepb.edu.br

${ }^{2}$ Laboratório de Ecologia Aquática - LEAq, Universidade Estadual da Paraíba - UEPB, Rua Baraúnas, 351, Bairro Universitário, CEP 58429-500, Campina Grande, PB, Brazil e-mail: gabijoanne@yahoo.com.br

\begin{abstract}
Aim: Resource partitioning has been recognized as a major driver affecting fish communities, with the potential to reduce interespecific competition. This is the result of differences in feeding apparatuses and feeding mode, location of the fish species in the water column and swimming ability, as well as type and size of prey and its availability. The present study surveys a highly limited aquatic system in semi-arid Brazil with regard to habitat and food availability, with very low diversity of fish, and poor in underwater habitat structures and prey, with the objective of understanding resource partitioning among fish species under such conditions. Methods: Three species of Cichlidae (Pisces: Perciformes) were sampled during the dry and wet seasons and had their stomach contents analyzed to evaluate food consumption. The resource partition among fish species was evaluated based on Pianka's niche overlap index and tested for significance against null models. Results: It was observed a low overlap among the study species in food resource use, with individuals tending to specialize to select some food items. This is likely the result of low natural variation in abundance of specific food items associated with fish preferences (both morphological and behavioral). Conclusions: These results support evidence that, in Brazilian semi-arid aquatic systems, coexistence of fish species seems to be enhanced by the partition of food items at specific trophic levels. Within this context, flow variability would have a key hole in fish coexistence by promoting a high diversity of aquatic habitat elements available for colonization of fish and their prey. Furthermore, food resources available to fish play an important role in this dynamics since prey foods are expected to vary in abundance as the habitat changes.
\end{abstract}

Keywords: fish; stomach content; drought; null model; species coexistence.

Resumo: Objetivos: A partição de recursos tem sido reconhecida como um importante fator que influencia comunidades de peixes, com o potencial de reduzir a competição interespecífica. Isto resulta de diferenças no trato digestivo e habito alimentar, localizaçáo das espécies de peixes na coluna de água e habilidade natatória, bem como tipo e tamanho da presa e da disponibilidade desta no ambiente. O presente estudo avalia a partição de itens alimentares presentes na dieta de peixes, em um sistema aquático do semiárido brasileiro que apresenta baixa diversidade de espécies de peixes e de estruturas subaquáticas que compóem o habitat. Objetivou-se compreender como três espécies de peixes particionam o limitado recurso disponível no ambiente. Métodos: Três espécies de Cichlidae (Pisces: Perciformes) foram amostradas durante períodos de seca e de chuva e estes tiveram seu conteúdo estomacal analisado para quantificar o consumo de itens alimentares. A partilha de recursos alimentares entre as espécies estudadas foi avaliada usando o índice de sobreposição de nicho de Pianka e testada para sua significância usando modelos nulos. Resultados: Foi observada uma baixa sobreposição alimentar entre as espécies estudadas, onde os indivíduos de cada espécie tenderam a se especializar consumindo itens alimentares específicos. Isto dado pela baixa abundância natural de itens 
alimentares associada com as preferências específicas (morfológicas e comportamentais) de cada espécie estudada. Conclusáo: Os resultados apresentados suportam outras evidências de que a coexistência de espécies de peixes em ambientes aquáticos do semiárido é mediada pela partição dos itens alimentares em níveis mais específicos. Nesse contexto, a variabilidade do fluxo de água teria um papel chave na coexistência de espécies por produzir uma alta diversidade de itens alimentares e heterogeneidade do habitat.

Palavras-chave: peixes; conteúdo estomacal; estiagem; modelo nulo; coexistência de espécies.

\section{Introduction}

The fish fauna of Brazilian semi-arid aquatic systems is diverse with the presence of innumerous endemic species (Rosa et al., 2003; Maltchik \& Medeiros, 2006). Nonetheless, several non-native fish species have been introduced in these systems as part of programs for water resource development, despite the fact that the introduction of exotic species often leads to a decrease in richness and abundance of native species in dryland river systems (Arthington et al., 1983; Bunn et al., 1999; Bunn \& Arthington, 2002).

In Brazil, water resource development policies emphasize construction of large dams, weirs, artificial channels and, more recently, large-scale inter-basin water transfers which represent one of the main threats to the ecological integrity of rivers (Baxter, 1977; Bunn \& Arthington, 2002; Agostinho et al., 2005). Furthermore, long-term programs of introduction of exotic species of fish, such as the Cyprinus carpio Linnaeus 1758 and Cichla ocellaris Bloch \& Schneider, 1801 (Gurgel \& Oliveira, 1987) in these artificial reservoirs have contributed to the degradation of the natural biodiversity in aquatic environments in semi-arid Brazil.

Fish species in reservoirs may present a greater trophic plasticity (Abelha \& Goulart, 2004), but the occurrence of specialists or generalists in a given habitat type is influenced by the food resources available (Abelha et al., 2001). In systems where there are few food items, generalist strategies would be expected (Roughgarden \& Feldman, 1975). In this context, a restricted food spectrum, that is, the preference for few food items, would not be advantageous for freshwater fish in systems highly subjected to water level changes, since the same food items will not be available during the entire hydrological cycle (Agostinho et al., 2007). Zaret $\&$ Rand (1971), for instance, demonstrate that the partitioning in food resource use is more effective, or evident, during periods of food scarcity, which highlights the importance of food availability in its partition by fish species.
Resource partition is seen as the differences in resource use by coexisting species, including food, habitat and other limiting factors. These factors correspond to the three dimensions in which resource segregation may occur: food, habitat and time (Wootton, 1990), food being the most important factor in resource partitioning among fish (Angermeier, 1982). Resource partitioning has been recognized as a major process affecting fish communities, with the potential to reduce interespecific competition (Ross, 1991), which is the result of differences in feeding apparatuses and feeding mode, location of the species in the water column and swimming ability, as well as type and size of prey (Medeiros \& Arthington, 2008a).

Within this context, the present study surveys a highly limited aquatic system in semiarid Brazil with regard to habitat and food availability, with very low diversity of fish, and poor in underwater habitat structures and prey (Medeiros et al., 2008; Medeiros et al., 2010; Silva et al., 2010; Medeiros et al., 2011). We evaluate the diets of three species of cichlid fish, Oreochromis niloticus (Linnaeus, 1758), Parachromis managuensis (Günther, 1867) and Geophagus brasiliensis (Quoy \& Gamard, 1824) with the aim of understanding resource partitioning among these species under conditions of limited food availability. Oreochromis niloticus is an introduced species from the African continent (Attayde et al., 2007). Studies refer to this species as an omnivore, with microalgae and plant material as its main food items (Oso et al., 2006). Parachromis managuensis is also an introduced cichlid from Central America (Barbosa \& Mendonça, 2006) and is considered a voracious piscivore (Agasen et al., 2006). Geophagus brasiliensis is the only native cichlid recorded in the study site. This species is typical of lentic environments, bottom dweller and omnivorous, feeding on insect larvae and zooplankton when young (less than $4 \mathrm{~cm}$ ) and adding gastropods, vegetable matter, sediment and algae to its diet as it grows (Lazzaro, 1991; Moraes et al., 2004). 


\section{Materials and Methods}

The present study was performed at the Gurjão reservoir (0842'13,6”'S; 36³6'35,5”W), an impoundment on the Salobro stream (Una River basin), which is located in the Buíque/Vale do Ipojuca area (sensu Tabarelli \& Silva, 2005) of northeastern Brazil. This site was chosen because previous studies show that this reservoir is very poor in fish species diversity (5 species during the study period), in underwater and littoral habitat structures and also in prey items available for fish consumers (Medeiros et al., 2008; Silva et al., 2010; Medeiros et al., 2011). Climate in the study area is semi-arid BSh (Peel et al., 2007) and the average annual temperature and precipitation are $25^{\circ} \mathrm{C}$ and $1095.9 \mathrm{~mm}$, respectively. Rainfall is concentrated between April and June and altitudes range between 800 and $1000 \mathrm{~m}$ (Rodal et al., 1998).

Sampling was conducted on two occasions during the wet and dry seasons of 2006. All collections were performed during daylight hours. Fish collections were performed in accordance with Medeiros et al. (2010) using four different types of sampling gear: a short beach seine net ( $4 \mathrm{~m}$ long, $1.5 \mathrm{~m}$ high and $5 \mathrm{~mm}$ mesh), a long beach seine net (20 $\mathrm{m}$ long, $2 \mathrm{~m}$ high and $12 \mathrm{~mm}$ mesh), one set of gill nets (30 m long and $1.5 \mathrm{~m}$ high, equally divided into three $10 \mathrm{~m}$ panels of 35,45 and $55 \mathrm{~mm}$ meshes) and a cast net ( $2.4 \mathrm{~m}$ high and $12 \mathrm{~mm}$ mesh). Gill nets were kept in the water for a period of 6 hours being checked at the third and sixth hour. The seine net hauls were approx. $10 \mathrm{~m}$ long for the large seine net and repeated 3-5 times, and 3 to $5 \mathrm{~m}$ long for the short seine net, being repeated 7-12 times. The cast net was repeated 12 times for each sampling occasion. Fish caught were fixed in $10 \%$ formalin neutralized with sodium tetraborate and later transferred to $75 \%$ ethanol. Collections were performed under license No. 032DIFAP/IBAMA from 23 March 2006.

The structure of the habitat was measured as physical and chemical variables, reservoir morphology, substrate composition and habitat structure. Physical and chemical variables were measured using portable equipment for dissolved oxygen $(\mathrm{mg} / \mathrm{L})$ and temperature $\left({ }^{\circ} \mathrm{C}\right.$ ) (Lutron DO-5510). Transparency (cm) was measured using a Secchi disk. Morphology was evaluated using GPS receiver for width $(\mathrm{cm})$ and a measuring pole for depth $(\mathrm{cm})$, both taken from three transects across the reservoir. The substrate composition and habitat structure were estimated in 9 to 12 survey points of $1 \mathrm{~m}^{2}$ measured in the margins. In each survey point, the proportional cover of the sediment composition (classified as mud, sand, gravel, and cobbles) and littoral and underwater structures (e.g., macrophytes, grass, submerged vegetation, overhanging vegetation, leaf litter, algae, and woody debris) were visually estimated (Medeiros et al., 2008).

For the stomach content analysis, a maximum of 15 specimens of each study species per sampling occasion was selected. In the laboratory, each individual fish was measured $(\mathrm{mm})$ for the standard length (SL). For the dietary analysis, the stomach of each fish was removed, blotted, placed in a Petri dish and observed with a stereomicroscope for macroscopic analysis of contents. The degree of stomach fullness was visually estimated assigning a score between 0 (empty) and 100 (fully distended with food), reflecting percentages of stomach volume occupied by food (Medeiros \& Arthington, 2008b). The proportional contribution of each food item to the diet of individual fish was estimated using an indirect volumetric method (Arthington, 1992; Pusey et al., 2000), where stomach items belonging to each food category are lumped together and squashed to a uniform depth of $1 \mathrm{~mm}$. The area covered was taken to represent the volumetric contribution of that food category to the total stomach contents in $\mathrm{mm}^{3}$. Given the high contribution of bottom sediment to the diet of $O$. niloticus, further analysis was performed to evaluate composition of microscopic food items. After the macroscopic evaluation on stereomicroscope, the stomach content was diluted to a volume of $10 \mathrm{~mL}$ with ethanol $70 \%$ and three sub-samples were analyzed using a binocular microscope (Silva et al., 2010). Microalgae were counted on three horizontal transects of the diluted stomach content mounted into an unsealed slide. Taxonomic classification of microalgae was based on Bicudo \& Menezes (2006).

To estimate prey available for fish, aquatic macroinvertebrates were collected from three subsamples of $40 \times 40 \times 2.5 \mathrm{~cm}$ of sediment randomly taken from the margins using a $\mathrm{D}$-shaped net $(40 \mathrm{~cm}$ wide and $250 \mu \mathrm{m}$ mesh). Samples were fixed in $4 \%$ formalin in the field and taken to the laboratory where they were preserved in $70 \%$ alcohol. Macroinvertebrate individuals were sorted, identified to the lowest possible level (usually family) and counted. Identification followed standard literature (Mccafferty, 1983; Borror \& Delong, 1988; Williams \& Feltmate, 1992). Zooplankton was collected using a plankton 
net (opening diameter $30 \mathrm{~cm}, 70 \mathrm{~cm}$ long and mesh size of $60 \mu \mathrm{m}$ ). The net was towed for a distance of $10 \mathrm{~m}$ on the surface of the water (see Medeiros et al., 2011) and the zooplankton was preserved in $4 \%$ formalin. In the laboratory, three sub-samples were taken from each sample and all individuals were identified (Suárez et al., 1996; Elmoor-Loureiro, 1997; Segers, 2007) and counted in a Sedgewick-Rafter counting cell $(1 \mathrm{~mL})$. Only rotiferans, cladocerans and copepods were considered in the present study. Fish abundance was standardized per unit of effort of capture, where the number of fish captured was divided by the number of hours or replicates of each sampling technique on each sampling occasion and site (Medeiros et al., 2010). All prey items are presented as proportional density (expressed as individuals per liter).

\subsection{Data analysis}

To calculate the contribution of a given food item to the diet of a fish species, the volume of each food item across stomachs was expressed as percentage. Frequency of occurrence (\%) was calculated as the number of times a food item occurred in the stomachs of a given species divided by the number of stomachs. Dietary breadth was estimated using the Shannon's diversity index. Temporal patterns of variation in food items and variation across species were evaluated using Nonmetric Multidimensional Scaling (NMDS), based on the relativized Bray-Curtis distance of the arcsine square root transformed data matrix. The Multiresponse Permutation Procedure (MRPP) (Biondini et al., 1985; Mccune \& Grace, 2002) was used to test for significance of differences in diet composition across sampling occasions and species. The value of " $\mathrm{A}$ " is presented as a measure of the degree of homogeneity between groups compared to random expectation. The Indicator Species Analysis (ISA) was used as a way to determine which food items were significant indicators of species diets. The indicator value (IV) for each item was calculated using the method of Dufrene \& Legendre (1997). This value is tested for significance using the Monte Carlo test (999 permutations). Statistical analyses $(\alpha=0.05)$ were performed on PC-ORD 4.27 (Mccune \& Mefford, 1999).

The feeding strategy and feeding preferences of fish were evaluated using a modification of the graphic method of Amundsen et al. (1996). Ordinarily, the prey-specific abundance is plotted against the frequency of occurrence of food items in stomachs on a two-dimensional graph (Amundsen et al., 1996). In the present study, the proportion of natural prey abundance (\%) in the environment is used instead of prey-specific abundance, thus allowing for the analysis of feeding strategies and niche width based on natural abundances of prey. Given that the unidentifiable digested matter is not measurable in the environment, it was removed from the data matrix for this analysis.

Volumetric dietary overlap was calculated using Pianka's overlap index $\left(\mathrm{O}_{\mathrm{jk}}\right)$. To determine niche overlap, dietary data was distributed into two matrices representing the wet and dry season diets. Entries in the matrixes were proportional volumes of a given food item consumed by a given species at each season. Niche overlap was calculated and statistically tested against null models using EcoSim 7.0 (Gotelli \& Entsminger, 2001). The program performs 1000 Monte Carlo randomizations to create pseudo-communities and statistically tests the mean niche overlap values for the species pairs between randomized communities and those in the real data matrix. Interspecific food partitioning might be occurring when the observed mean overlap values are significantly lower than those expected by chance, whereas similar foraging patterns lead to values higher than those expected by chance (Albrecht \& Gotelli, 2001). For the present study two different algorithms were used to test for non-random patterns of resource utilization (Winemiller \& Pianka, 1990): the RA3 algorithm, where entries in each row are randomly reshuffled (this procedure preserves the niche breadth degree of specialization of the species, but permits the utilization of any resource available in the matrix) (Albrecht \& Gotelli, 2001); and the RA4 algorithm, where only entries different from zero are reshuffled in each row, thus both the niche breadth and zero states are retained. That means that if a species has not consumed a certain item in the real data, it will not be allowed the consumption in the simulated assemblage (Albrecht \& Gotelli, 2001). It was also assumed that resource states are considered to be equiprobable (equally abundant or usable by all species). Both algorithms were applied to each of the two (wet and dry) data matrices.

\section{Results}

A total of 90 stomachs were analyzed and 26 of these were empty (Table 1). The average size of fish ranged from 53 to $80 \mathrm{~mm}$, with $G$. brasiliensis being the largest species on average. 
Table 1. Data on fish size, stomach fullness and food items consumed by $O$. niloticus, P. managuensis and G. brasiliensis.

\begin{tabular}{|c|c|c|c|c|c|c|}
\hline & \multicolumn{2}{|c|}{ O. niloticus } & \multicolumn{2}{|c|}{ P. managuensis } & \multicolumn{2}{|c|}{ G. brasiliensis } \\
\hline $\mathrm{N}$ & \multicolumn{2}{|c|}{30} & \multicolumn{2}{|c|}{30} & \multicolumn{2}{|c|}{30} \\
\hline $\mathrm{SL} \mathrm{mm} \mathrm{( \pm SD)}$ & \multicolumn{2}{|c|}{$53( \pm 8.1)$} & \multicolumn{2}{|c|}{$65( \pm 4.1)$} & \multicolumn{2}{|c|}{$80( \pm 18.3)$} \\
\hline SL mm (min-max) & \multicolumn{2}{|c|}{$40-69$} & \multicolumn{2}{|c|}{$59-73$} & \multicolumn{2}{|c|}{$53-120$} \\
\hline Empty stomachs & \multicolumn{2}{|c|}{2} & \multicolumn{2}{|c|}{14} & \multicolumn{2}{|c|}{10} \\
\hline Niche Breadth & \multicolumn{2}{|c|}{$0.06( \pm 0.15)$} & \multicolumn{2}{|c|}{$0.51( \pm 0.33)$} & \multicolumn{2}{|c|}{$0.65( \pm 0.38)$} \\
\hline Food items (\%) & Vol. & F.O. & Vol. & F.O. & Vol. & F.O. \\
\hline Sediment & 98.5 & 100.0 & 0.0 & 0.0 & 23.4 & 80.0 \\
\hline Chironomidae (Larvae) & 0.0 & 0.0 & 0.0 & 0.0 & 2.0 & 35.0 \\
\hline Calanoida & 0.6 & 10.7 & 1.9 & 12.5 & 0.0 & 0.0 \\
\hline Cladocera & 0.5 & 14.3 & 1.8 & 37.5 & 0.0 & 0.0 \\
\hline Fish scales & 0.4 & 21.4 & 30.0 & 93.8 & 6.1 & 30.0 \\
\hline Vegetable matter & 0.1 & 10.7 & 0.0 & 0.0 & 9.2 & 35.0 \\
\hline Digested matter & 0.0 & 0.0 & 11.1 & 62.5 & 58.3 & 90.0 \\
\hline Sand & 0.0 & 0.0 & 4.0 & 25.0 & 0.0 & 0.0 \\
\hline Fish remaining & 0.0 & 0.0 & 33.8 & 37.5 & 0.0 & 0.0 \\
\hline Shrimp & 0.0 & 0.0 & 17.3 & 18.8 & 0.0 & 0.0 \\
\hline Algae (filamentous) & 0.0 & 0.0 & 0.0 & 0.0 & 0.6 & 25.0 \\
\hline Mollusk & 0.0 & 0.0 & 0.0 & 0.0 & 0.3 & 5.0 \\
\hline
\end{tabular}

This species and $P$. managuensis showed the highest numbers of empty stomachs. Richer diets were observed for $G$. brasiliensis (niche breadth $=0.5$ ) and $P$. managuensis (niche breadth=0.6) with the former species feeding mostly on sediment, but also showing high proportion of digested material in the stomach contents. Parachromis managuensis fed mostly on fish and shrimp and O. niloticus diet was based mostly on sediment (niche breath=0.06) (Table 1, Figure 1). Frequency of occurrence of food items in fish stomachs agreed with volumetric data, where sediment and digested matter showed high frequency of occurrence in the stomachs of G. brasiliensis. Nonetheless, chironomids, fish scales, vegetable matter and filamentous algae were also frequently found in the stomachs of this species. Parachromis managuensis showed high frequency of ingestion of zooplankton, sand and digested matter, and $O$. niloticus also showed high frequency of zooplankton with further contributions in frequency by fish scales and vegetable matter (Table 1).

Nonmetric Multidimensional Scaling (NMDS) (Figure 2) showed clear segregation in fish diets across species (MRPP, $\mathrm{A}=0.48, \mathrm{p}<0.01$ ) but no differences between seasons for each species (MRPP, $\mathrm{A}=0.005, \mathrm{p}=0.22$ ). It is important to note that the average distance among individuals in the ordination space was higher for $P$. managuensis $(0.42)$ and $G$. brasiliensis (0.31) than for O. niloticus (0.07), when compared with the grand mean (centroid) of 0.66 , indicating less individual variation in

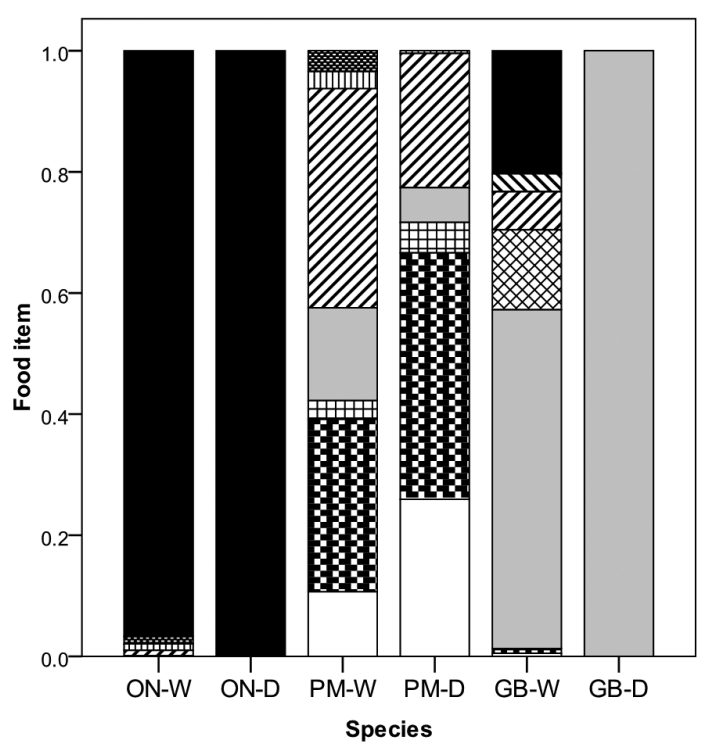

\begin{tabular}{|c|c|}
\hline 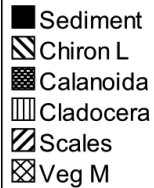 & 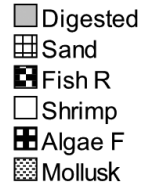 \\
\hline
\end{tabular}

Figure 1. Proportional composition of food items to the diet of $O$. niloticus (ON), P. managuensis (PM) and $G$. brasiliensis (GB) during the wet (W) and dry (D) periods. See Table 1 for full food items names.

diet composition for $O$. niloticus. Indicator Species Analysis (ISA) showed that food items that significantly contributed to the segregation of the study species diets were sediment (IV=80.8, $\mathrm{p}=0.001$ ) for $O$. niloticus; fish scales (IV=77.1, 


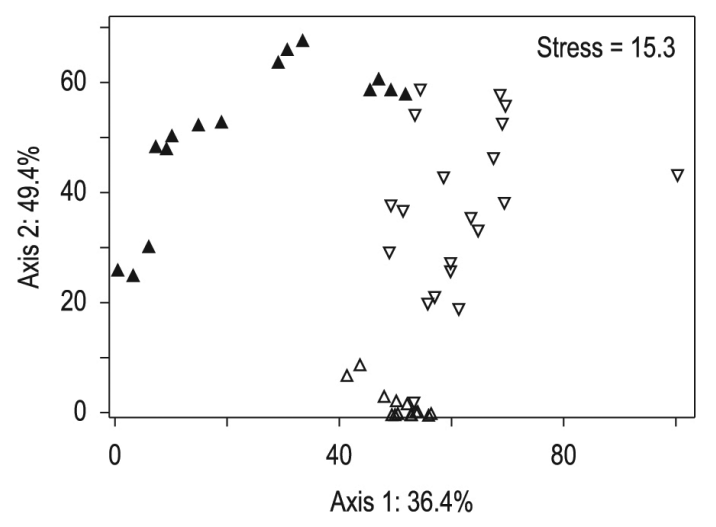

Figure 2. NMDS results for individual fish diet composition across species $(\triangle=O$. niloticus, $\nabla=G$. brasiliensis, $\boldsymbol{\Delta}=P$. managuensis), with variance explained for each axis and stress value.

$\mathrm{p}=0.001$ ), fish remainings (IV=37.5, $\mathrm{p}=0.001)$, sand $(I V=25.0, p=0.003)$, Cladocera $(I V=29.4, p=0.007)$ and shrimp (IV=18.7, $\mathrm{p}=0.015)$ for $P$. managuensis; and chironomids $(\mathrm{IV}=35.0, \mathrm{p}=0.001)$, digested matter $(I V=75.6, p=0.001)$, vegetable matter $(\mathrm{IV}=34.8, \mathrm{p}=0.004)$ and algae $(\mathrm{IV}=25.0, \mathrm{p}=0.005)$ for $G$. brasiliensis.

Environmental variables measured showed little variation and the study site presented well oxygenated, cool and transparent waters (Table 2). Site morphology indicated a large shallow reservoir, with low temporal variation (shown by the standard deviations of the averages), and long water retention, as shown by the absence of water flow during the study period. Habitat was composed mostly of low proportional cover of macrophytes and algae, and the substrate composition was dominated by mud (henceforth referred to as sediment). Natural abundances of food items were higher for Copepoda (among the zooplankton), Thiaridae (among the mollusks), larvae of chironomids (among the insects), sediment and $P$. managuensis and $O$. niloticus (among the fish) (Table 3 ).

The feeding strategy plots based on frequency of occurrence of food items in the stomach contents of the study species and natural abundances of prey items in the environment (modified from Amundsen et al., 1996) showed that most food items consumed had frequency of occurrence lower than $50 \%$, being arrayed to the left of the plots (Figure 3). In general, sediment was a dominant food item to the diets of $O$. niloticus and $G$. brasiliensis, being both frequent in the diet and abundant in the environment (Table 3). Despite the fact that fish scales were abundant in the environment, these items were not frequent in the
Table 2. Environmental variables (average \pm SD) collected in the study site.

\begin{tabular}{cc}
\hline \multicolumn{2}{c}{ Morphology } \\
\hline Altitude $(\mathrm{m})$ & 713 \\
Water velocity $(\mathrm{m} / \mathrm{s})$ & 0.0 \\
Maximum bank slope & 30.0 \\
Maximum depth $(\mathrm{cm})$ & $65.0( \pm 4.2)$ \\
Littoral depth $(\mathrm{cm})$ & $313.7( \pm 17.4)$ \\
Site width $(\mathrm{m})$ & $26.7( \pm 2.8)$ \\
\hline \multicolumn{2}{c}{ Water variables } \\
\hline Water temperature $\left({ }^{\circ} \mathrm{C}\right)$ & $6.1( \pm 3.3)$ \\
Dissolved oxygen $(\mathrm{mg} / \mathrm{L})$ & $42.1( \pm 13.7)$ \\
\hline Transparency $(\mathrm{cm})$ & $12.8( \pm 22.6)$ \\
\hline Habitat composition $(\%)$ \\
\hline Macrophyte cover & $5.2( \pm 6.5)$ \\
Littoral grass & $7.3( \pm 12.5)$ \\
Submerged vegetation & $0.9( \pm 1.6)$ \\
Overhanging vegetation & 0.0 \\
Leaf litter & $17.3( \pm 3.1)$ \\
Algae & 0.0 \\
Root masses & $0.9( \pm 0.7)$ \\
Woody debris & $94.4( \pm 4.6)$ \\
Substrate composition $(\%)$ \\
\hline Mud & $3.9( \pm 2.0)$ \\
Sand & $1.7( \pm 0.4)$ \\
Gravel & 0.0 \\
Cobbles & 0.0 \\
Rocks & 0.0 \\
Bedrock &
\end{tabular}

Table 3. Natural abundance (\%) of possible food items measured during the study period.

\begin{tabular}{cc}
\hline & $\%$ \\
\hline Zooplankton & 12.26 \\
\hline Copepoda & 6.48 \\
Rotifera & 4.19 \\
Cladocera & \\
\hline Mollusk & 9.61 \\
\hline Thiaridae & 1.86 \\
Planorbidae & 0.31 \\
Ampularidae & \\
\hline Insect & 8.99 \\
\hline Chironomidae (larvae) & 0.62 \\
Chironomidae (pupae) & 0.31 \\
Baetidae & 0.31 \\
Gomphidae & \\
\hline Other & 21.66 \\
\hline Sediment (mud) & 4.61 \\
Aquatic vegetation & 3.97 \\
Algae & 0.93 \\
Oligochaeta & 0.89 \\
Sand & 11.89 \\
Fish & 9.01 \\
\hline Astyanax fasciatus & 1.54 \\
\hline Parachromis managuensis & 0.45 \\
\hline Geophagus brasiliensis & 0.04 \\
\hline
\end{tabular}



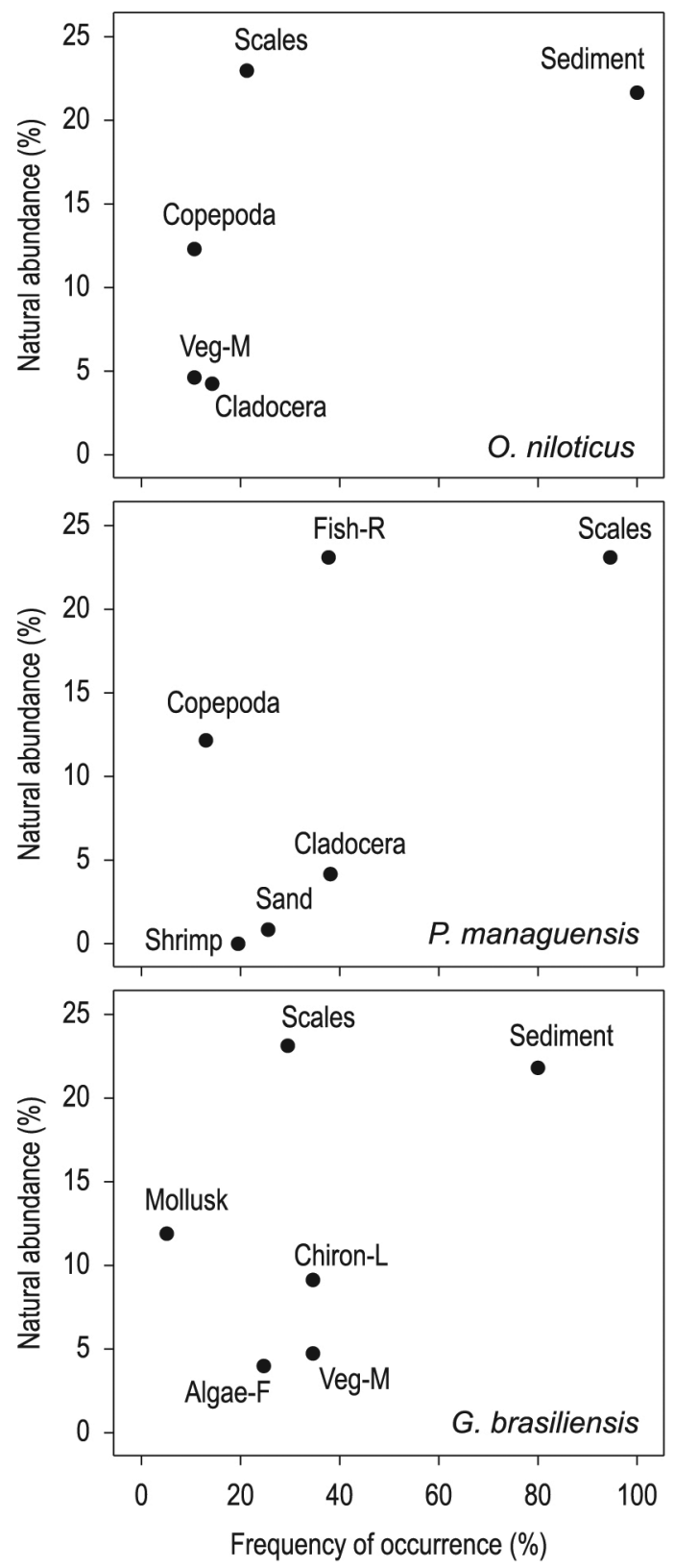

Figure 3. The feeding strategy diagram of food items natural abundance (\%) plotted against frequency of occurrence (\%) of food items in the stomach contents of the study species (modified from Amundsen et al. (1996)). diet of these species. All other food items consumed by $O$. niloticus and $G$. brasiliensis were not abundant in the environment yet consumed in lower frequency. Geophagus brasiliensis was more selective than $O$. niloticus, feeding on chironomids, vegetable matter and algae, even in lower natural abundances. Parachromis managuensis took advantage of higher abundances of its natural prey feeding frequently on fish. However, this species was highly selective for Cladocera, shrimp and sand, which showed very low natural abundances but were found in medium frequencies in their stomachs. We believe that, in the preset study, fish scales are found in diets resulting from advanced stages of digestion of prey fish consumed, and that sand is eaten in association with shrimp which are bottom dwellers.

According to the null models of Pianka's index, the diet overlap among the study species was low $\left(\mathrm{O}_{\mathrm{jk}}<0.41\right)$, with the highest overlap being observed between $O$. niloticus and $G$. brasiliensis $\left(\mathrm{O}_{\mathrm{jk}}=0.40\right)$ (Table 4). The overlap values between the dry and wet seasons for each species was high $(>0.87)$ (Table 4), which further corroborates previous analysis showing no temporal variation in diets. Considering proportional food items volume of the three study species separately for the dry and wet seasons, niche overlap was also low $\left(\mathrm{O}_{\mathrm{jk}}\right.$ observed mean for the wet season $=0.23$ and $\mathrm{O}_{\mathrm{jk}}$ observed mean for the dry season $=0.18$ ). Randomizations performed separately for temporal (dry and wet season) data produced no significant difference between the observed and expected niche overlap for both wet season (RA3 algorithm: p observed $<$ expected $=0.71$ and $\mathrm{p}$ observed $>$ expected $=$ 0.29; RA4 algorithm: p observed $<$ expected $=0.75$ and p observed $>$ expected $=0.25$ ) and dry season (RA3 algorithm: $\mathrm{p}$ observed $<$ expected $=0.66$ and p observed $>$ expected $=0.34$; RA4 algorithm: p observed $<$ expected $=0.70$ and $\mathrm{p}$ observed $>$ expected $=0.30)$. Therefore, the values of diet overlap across species were not significantly different from those expected by chance (null communities)

Table 4. Pianka's overlap index of diet across fish species and seasons during the study period.

\begin{tabular}{cccccccc}
\hline & \multicolumn{2}{c}{ O. niloticus } & \multicolumn{2}{c}{$\boldsymbol{P}$ managuensis } & \multicolumn{2}{c}{ G. brasiliensis } \\
\hline O. niloticus & & Wet & Dry & Wet & Dry & Wet & Dry \\
\hline \multirow{3}{*}{ P. managuensis } & Wet & - & & & & & \\
& Dry & 0.9998 & - & & & & \\
& Wet & 0.0081 & $7.5 \mathrm{E}-6$ & - & & - & - \\
\hline
\end{tabular}


Table 5. Proportional abundance of microalgae genera observed in the stomach contents of $O$. niloticus during the study period.

\begin{tabular}{|c|c|c|c|c|c|}
\hline \multicolumn{2}{|l|}{ Bacillariophyceae } & \multicolumn{2}{|l|}{ Cyanophyceae } & \multicolumn{2}{|l|}{ Oedogoniophyceae } \\
\hline Achnanthes sp. & 13.11 & Anabaena sp. & 13.82 & Oedogonium sp. & 3.40 \\
\hline Amphora sp. & 3.54 & Aphanocapsa sp. & 4.96 & & \\
\hline Cocconeis sp. & 0.28 & Aphanothece sp. & 3.05 & Zygnemaphyceae & \\
\hline Cymbella sp. & 0.64 & Chroococcus sp. & 1.56 & Closterium sp. & 0.07 \\
\hline Epithemia sp. & 0.07 & Coelomoron sp. & 0.28 & Spirogyra sp. & 0.28 \\
\hline Eunotia sp. & 0.07 & Coelosphaerium sp. & 0.07 & & \\
\hline Gomphonema sp. & 1.56 & Gloeotrichia sp. & 0.07 & & \\
\hline Gyrosigma sp. & 3.83 & Johannesbaptista sp. & 0.14 & & \\
\hline Navicula sp. & 1.77 & Lyngbya sp. & 5.74 & & \\
\hline Nitzschia sp. & 0.35 & Merismopedia sp. & 0.43 & & \\
\hline Surirella sp. & 0.21 & Nodularia sp. & 1.63 & & \\
\hline & & Planktothrix sp. & 0.14 & & \\
\hline Chlorophyceae & & Spirulina sp. & 0.14 & & \\
\hline Coelastrum sp. & 0.07 & & & & \\
\hline Oocystis sp. & 6.17 & Euglenophyceae & & & \\
\hline & & Trachelomonas sp. & 0.07 & & \\
\hline Coscinodiscophyceae & & & & & \\
\hline Aulacoseira sp. & 28.21 & Fragilariophyceae & & & \\
\hline Cyclotella sp. & 0.21 & Fragilaria sp. & 3.76 & & \\
\hline Melosira sp. & 0.28 & & & & \\
\hline
\end{tabular}

$(p>0.05)$, suggesting that these values have a high probability of being random, and thus showing no evidence of resource sharing.

Microscopic analysis of the stomach contents of $O$. niloticus showed the occurrence of mostly microalgae, which were likely ingested with the sediment. A total of 34 genera was recorded in the stomach contents of $O$. niloticus. The most abundant algae were Cyanophyceae 32.0\%, Coscinodiscophyceae $28.7 \%$, Bacillariophyceae 25.4\%, Chlorophyceae 6.2\%, Fragilariophyceae $3.8 \%$, Oedogoniophyceae $3.4 \%$, Zignemaphyceae $0.6 \%$ and Euglenophyceae $0.1 \%$ (Table 5).

\section{Discussion}

Aquatic systems in the tropics are known for their variety of fish species, adapted to consume food resources from a range of different sources (aquatic and terrestrial/animal and vegetal) (Lowe-Mcconnell, 1987). The present study surveyed a site that was poor in fish richness and in food and habitat resources available for fish (Medeiros et al., 2008; Silva et al., 2010; Medeiros et al., 2011). As a consequence, diet composition was narrow, with the study fish species consuming few food items from the short range available, compared with the far greater range of food items reported for the study species in the literature (Abelha \& Goulart, 2004; Barbosa \& Mendonça, 2006; Oso et al., 2006). In general, the study species maintained their expected diet composition with $G$. brasiliensis being mostly omnivorous and $P$. managuensis being piscivourous, both showing greater breadth of food items than $O$. niloticus, whose diet was based on microalgae from the sediment. Feeding on harder to digest items, such as bottom sediment or detritus in order to extract more nutritious food resources has been reported for other fish species in dryland aquatic systems (Silva et al., 2010; Medeiros \& Arthington, 2011). There is evidence indicating that these more refractory components are physically separated and/or the nutritious component selectively digested (Bowen, 1984).

Overall morphological and behavioral differences among the study species (Meyer, 1987; Wimberger, 1991; Toguyeni et al., 1997) most likely led to the observed differences in dietary composition, but differences between individuals of the same species and seasons were low, mostly so for $O$. niloticus. Populations of species with generalist feeding behavior will tend to be made either of individuals with narrow but different dietary breadths or individuals with shared broader breadths (Pianka, 1994). In the present study, the low natural diversity of food items and habitat types may have led to the overall high similarity in diet composition among individuals of $O$. niloticus. However, the more generalist species ( $G$. brasiliensis and P. managuensis) showed comparatively (with $O$. niloticus) less similar 
individual dietary composition, which can indicate a greater degree of individual specialization. This is corroborated by the fact that the more generalist species showed also more indicator food items (fish scales, fish remainings, sand, Cladocera and shrimp for $P$. managuensis; and chironomids, vegetable matter and algae for $G$. brasiliensis) when compared to $O$. niloticus, which had only sediment as indicator food item for the species.

Seasonal (wet/dry) variation in diet composition of the study species was not significant, as demonstrated by the multivariate analyses. This is likely the result of a lack of variation in natural abundance of prey items during the present study, which accompanied the overall lack of temporal variation in the morphological and water variables characteristics in the study site. The dynamics of the aquatic habitat has been reported as a basic framework affecting the colonization of the aquatic fauna and flora (Martin-Smith, 1998), which in turn sustains fish consumers (Mugodo et al., 2006). Furthermore, most food items with low proportional natural abundance were consumed in low frequency by the study species, indicating that their availability in the environment is an important determinant of food choice (Prejs \& Prejs, 1987). Interestingly, dominant food items in the diets of $O$. niloticus and $G$. brasiliensis were also abundant in the environment (except for fish scales). Nevertheless, $G$. brasiliensis and P. managuensis were more selective than $O$. niloticus, both feeding on items with lower natural abundances (such as chironomids and vegetable matter and cladocerans, respectively) regardless of the higher natural abundance of other items, such as mollusks and copepods (respectively).

Null models showed that diet overlap among the study species was low and that the seasonal overlap for each species was high. This further corroborates previous arguments showing no temporal variation in diets, and evidence of resource partitioning among the species. The fact that each cichlid species presented specific preferences, resulting from morphological and behavioral characteristics, for some food items is the most likely cause for the partition in food resources, that is each species feeding on few food items, therefore, not sharing with other species. Lower competition of species in Brazilian semi-arid aquatic systems has been proposed by Silva et al. (2010), on the basis that fish select from a wide range of food items available. But that study was performed on species that feed on different trophic levels in habitats richer in food items, fish species and underwater structures.
Two interpretations can be made from the data present in this study, to explain why diet did not overlap. The first is that the study species are competing against each other and therefore partitioning the resource available (Corrêa et al., 2011). That could be supported by the evidence from the present study showing that resource available is scarce and habitat available is not diverse; and that the three species coexist in the same habitat, since they were captured by the same sampling techniques employing the same sampling effort. The second interpretation is that the fish species have naturally different feeding habits and feeding apparatus morphology (Meyer, 1987; Wimberger, 1991; Toguyeni et al., 1997), thus segregating food items without competition per se. This is supported by the fact that, G. brasiliensis and $O$. niloticus, which are more similar in feeding apparatus morphology, also showed greater overlap, feeding largely on sediment.

Differences in underwater and marginal aquatic elements across variable habitat types have been reported for semi-arid aquatic systems of Brazil (Medeiros et al., 2008). The results of the present study provide evidence that the dietary composition of fish is influenced by the availability and composition of prey items, in conditions of low prey diversity and poor habitat structure, therefore associated with low spatial changes in the environment. Given the relatively low range of food items consumed, the results suggest that the lack of overall habitat variability and consequently low variability regarding the array of food items available, led to few and dominant food items consumed by the study species of fish. In the present study, a narrow range of food items was consumed by the fish species, as each of the species showed specific dietary preferences with predominance of items observed in greater natural abundance in the environment. These results and the low overlap in food resource use indicate that in the presence of restricted availability of resources (food and habitat) fish species and individuals tend to specialize to select some resources. This is likely the result of low natural variation in abundance of specific food items associated with fish morphological and behavioral traits. These results support evidence that in Brazilian semi-arid aquatic systems coexistence of fish species seems to be enhanced by the highly variable water flow and by the high diversity of aquatic habitat elements available for colonization of fish and their prey. Furthermore, food resources available to fish play an important role in this 
dynamics since prey foods are expected to vary in abundance as the habitat changes. Given the overall lack of information on resource partitioning and feeding preferences of fish for the Brazilian aquatic systems, further studies need to be performed to evaluate the patterns observed in the present study in other systems, such as intermittent streams and natural shallow lakes, in order to better understand coexistence of fish in these systems.

\section{Acknowledgements}

The authors are grateful to Dr. Telton P. A. Ramos (Universidade Federal da Paraíba) for fieldwork assistance and confirmation of species identification. This research was supported by funds from UEPB/FAPESQ (68.0006/2006.0) and Projeto de Pesquisa em Biodiversidade do Semi-árido (PPBio Semi-Árido). Elvio Medeiros is grateful to UEPB/DCR/CNPq (350082/2006-5) for scholarship granted. Elvio Medeiros holds a Brazilian Research Council (CNPq) Research Productivity Grant (CNPq 312028/2012-1).

\section{References}

ABELHA, M.C.F. and GOULART, E. Oportunismo trófico de Geophagus brasiliensis (Quoy \& Gaimard, 1824) (Osteichthyes, Cichlidae) no reservatório de Capivari, Estado do Paraná, Brasil. Acta Scientiarum. Biological Sciences, 2004, 26(1), 37-45.

ABELHA, M.C.F., AGOSTINHO, A.A. and GOULART, E. Plasticidade trófica em peixes de água doce. Acta Scientiarum. Biological Sciences, 2001, 23(2), 425-434.

AGASEN, E.V., CLEMENTE, J.P., ROSANA, M.R. and KAWIT, N.S. Biological investigation of Jaguar Guapote Parachromis managuensis (Gunther) in Taal Lake, Philippines. Journal of Environmental Science and Management, 2006, 9(2), 20-30.

AGOSTINHO, A.A., GOMES, L.C. and PELICICE, F.M. Ecologia e manejo de recursos pesqueiros em reservatórios do Brasil. Maringá: EDUEM, 2007.

AGOSTINHO, A.A., THOMAZ, S.M. and GOMES, L.C. Conservation of the biodiversity of Brazil's inland waters. Conservation Biology, 2005, 19(3), 646-652. http://dx.doi.org/10.1111/j.15231739.2005.00701.x.

ALBRECHT, M. and GOTELLI, N.J. Spatial and temporal niche partitioning in grassland ants. Oecologia, 2001, 126(1), 134-141. http://dx.doi. org/10.1007/s004420000494.

AMUNDSEN, P.-A., GABLER, H.-M. and STALDVIK, F.J. A new approach to graphical analysis of feeding strategy from stomach contents data - modification of the Costello (1990) method. Journal of Fish Biology, 1996, 48(4), 607-614.

ANGERMEIER, P.L. Resource seasonality and fish diets in an Illinois stream. Environmental Biology of Fishes, 1982, 7(3), 251-264. http://dx.doi.org/10.1007/ BF00002500.

ARTHINGTON, A.H. Diets and trophic guild structure of freshwater fishes in Brisbane streams. Proceedings of the Royal Society of Queensland, 1992, 102, 31-47.

ARTHingTON, A.H., MiLTON, D.A. and MCKAY, R.J. Effects of urban development and habitat alterations on the distribution and abundance of native and exotic freshwater fish in the Brisbane region, Queensland. Australian Journal of Ecology, 1983, 8(2), 87-101. http://dx.doi. org/10.1111/j.1442-9993.1983.tb01597.x.

ATTAYDE, J.L., OKUN, N., BRASIL, J., MENEZES, R. and MESQUITA, P. Os impactos da introdução da tilápia do Nilo, Oreochromis niloticus, sobre a estrutura trófica dos ecossistemas aquáticos do Bioma Caatinga. Oecologia Brasiliensis, 2007, 11(3), 450461. http://dx.doi.org/10.4257/oeco.2007.1103.13.

BARBOSA, J.M. and MENDONÇA, I.T.L. Comportamento social e crescimento em Parachromis managuensis (Günther, 1867) (Pisces, Cichlidae): uma espécie introduzida no Brasil. Revista Brasileira de Engenharia de Pesca, 2006, 1(1), 65-74.

BAXTER, R.M. Environmental effects of dams and impoundments. Annual Review of Ecology and Systematics, 1977, 8(1), 255-283. http://dx.doi. org/10.1146/annurev.es.08.110177.001351.

BICUDO, C.E.M. and MENEZES, M. Gêneros de algas de águas continentais do Brasil. São Carlos: RIMA, 2006, $502 \mathrm{p}$.

BIONDINI, M.E., BONHAM, C.D. and REDENTE, E.F. Secondary successional patterns in a sagebrush (Artemisia tridentata) community as they relate to soil disturbance and soil biological activity. Vegetatio, 1985, 60(1), 25-36. http://dx.doi.org/10.1007/ BF00053909.

BORROR, D.J. and DELONG, D.M. Introdução ao estudo dos insetos. São Paulo, SP: Edgard Blücher, 1988, $653 \mathrm{p}$.

BOWEN, S.H. Detritivory in neotropical fish communities. In T.M. ZARET, ed. Evolutionary ecology of neotropical freshwater fishes. Netherlands: Springer Netherlands, 1984, pp. 59-66. http:// dx.doi.org/10.1007/978-94-015-7682-6_4.

BUNN, S.E. and ARTHINGTON, A.H. Basic principles and ecological consequences of altered flow regimes for aquatic biodiversity. Environmental Management, 2002, 30(4), 492-507. http://dx.doi. org/10.1007/s00267-002-2737-0. PMid:12481916

BUNN, S.E., DAVIES, P.M. and MOSISCH, T.D. Ecosystem measures of river health and their response to riparian and catchment degradation. Freshwater 
Biology, 1999, 41(2), 333-345. http://dx.doi. org/10.1046/j.1365-2427.1999.00434.x.

CORRÊA, C.E., ALBRECHT, M.P. and HAHN, N.S. Patterns of niche breadth and feeding overlap of the fish fauna in the seasonal Brazilian Pantanal, Cuiabá River basin. Neotropical Ichthyology, 2011, 9(3), 637-646. http://dx.doi.org/10.1590/S167962252011000300017.

DUFRENE, M. and LEGENDRE, P. Species assemblages and indicator species: the need for a flexible asymmetrical approach. Ecological Monographs, 1997, 67(3), 345-366.

ELMOOR-LOUREIRO, L.M.A. Manual de identificação de cladóceros límnicos do Brasil. Brasilia, DF: Universa, 1997, $156 \mathrm{p}$.

GOTELLI, N.J. and ENTSMINGER, G.L. EcoSim: Null models software for ecology. Version 7.0. Acquired Intelligence Inc. \& Kesey-Bear, 2001.

GURGEL, J.J.S. and OLIVEIRA, A.G. Efeitos da introdução de peixes e crustáceos no semi-árido do Nordeste brasileiro. Coleção Mossoroense, 1987, 453, 7-32.

LAZZARO, X. Feeding convergence in South American and African zooplanktivorous cichlids Geophagus brasiliensis and Tilapia rendalli. Environmental Biology of Fishes, 1991, 31(3), 283-293. http://dx.doi. org/10.1007/BF00000693.

LOWE-MCCONNELL, R.H. Ecological studies in tropical fish communities. London: Cambridge University Press, 1987, 382 p. http://dx.doi. org/10.1017/CBO9780511721892.

MALTCHIK, L. and MEDEIROS, E.S.F. Conservation importance of semi-arid streams in north-eastern Brazil: implications of hydrological disturbance and species diversity. Aquatic Conservation: Marine and Freshwater Ecosystems, 2006, 16(7), 665-677. http:// dx.doi.org/10.1002/aqc.805.

MARTIN-SMITH, K.M. Relationships between fishes and habitat in rainforest streams in Sabah, Malaysia. Journal of Fish Biology, 1998, 52(3), 458-482.

MCCAFFERTY, W.P. Aquatic entomology: the fishermen's guide and ecologists' illustrated guide to insects and their relatives. Sudbury, MA: Jones and Bartlett Publishers, 1983, $448 \mathrm{p}$.

MCCUNE, B. and GRACE, J.B. Analysis of ecological communities. Gleneden Beach, Oregon: $\mathrm{MjM}$ Software Design, 2002, $300 \mathrm{p}$.

MCCUNE, B. and MEFFORD, M.J. PCORD. Multivariate Analysis of Ecological Data. Gleneden Beach, Oregon: MjM Software Design, 1999.

MEDEIROS, E.S.F. and ARTHINGTON, A.H. Allochthonous and autochthonous carbon sources for fish in floodplain lagoons of an Australian dryland river. Environmental Biology of Fishes, 2011,
90(1), 1-17. http://dx.doi.org/10.1007/s10641010-9706-x.

MEDEIROS, E.S.F. and ARTHINGTON, A.H. Diel variation in food intake and diet composition of three native fish species in floodplain lagoons of the Macintyre River, Australia. Journal of Fish Biology, 2008a, 73(4), 1024-1032. http://dx.doi. org/10.1111/j.1095-8649.2008.01959.x.

MEDEIROS, E.S.F. and ARTHINGTON, A.H. The importance of zooplankton in the diets of three native fish species in floodplain waterholes of a dryland river, the Macintyre River, Australia. Hydrobiologia, 2008b, 614(1), 19-31. http://dx.doi.org/10.1007/ s10750-008-9533-7.

MEDEIROS, E.S.F., NOIA, N.P., ANTUNES, L.C. and MELO, T.X. Zooplankton composition in aquatic systems of semi-arid Brazil: spatial variation and implications of water management. Pan-American Journal of Aquatic Sciences, 2011, 6, 290-302.

MEDEIROS, E.S.F., SILVA, M.J. and RAMOS, R.T.C. Application of catchment- and local-scale variables for aquatic habitat characterization and assessment in the Brazilian semi-arid region. Neotropical Biology and Conservation, 2008, 3(1), 13-20.

MEDEIROS, E.S.F., SILVA, M.J., FIGUEIREDO, B.R.S., RAMOS, T.P.A. and RAMOS, R.T.C. Effects of fishing technique on assessing species composition in aquatic systems in semi-arid Brazil. Brazilian Journal of Biology, 2010, 70(2), 255-262. http:// dx.doi.org/10.1590/S1519-69842010000200004. PMid:20549058

MEYER, A. Phenotypic plasticity and heterochrony in Cichlasoma managuense (Pisces, Chichlidae) and their implications for speciation in Cichlid fishes. Evolution; International Journal of Organic Evolution, 1987, 41(6), 1357-1369. http://dx.doi. org/10.2307/2409100.

MORAES, M.F.P.G., BARBOLA, I.F. and DUBOC, L.F. Feeding habits and morphometry of digestive tracts of Geophagus brasiliensis (Osteichthyes, Cichlidae), in a lagoon of high Tibagi river, Paraná State, Brazil. Publicatio UEPG: Ciências Biológicas e da Saúde, 2004, 10(1), 37-45.

MUGODO, J., KENNARD, M.J., LISTON, P., NICHOLS, S., LINKE, S., NORRIS, R.H. and LINTERMANS, M. Local stream habitat variables predicted from catchment scale characteristics are useful for predicting fish distribution. Hydrobiologia, 2006, 572(1), 59-70. http://dx.doi.org/10.1007/ s10750-006-0252-7.

OSO, J.A., AYODELE, I.A. and FAGBUARO, O. Food and feeding habits of Oreochromis niloticus (L.) and Sarotherodon galilaeus (L.) in a tropical reservoir. World Journal of Zoology, 2006, 1(2), 118-121.

PEEL, M.C., FINLAYSON, B.L. and MCMAHON, T.A. Updated world map of the Köppen-Geiger 
climate classification. Hydrology and Earth System Sciences, 2007, 11(5), 1633-1644. http://dx.doi. org/10.5194/hess-11-1633-2007.

PIANKA, E.R. Evolutionary ecology. New York: HarperCollins, 1994, 486 p.

PREJS, A. and PREJS, K. Feeding of tropical freshwater fishes: seasonality in resource availability and resource use. Oecologia, 1987, 71(3), 397-404. http://dx.doi. org/10.1007/BF00378713.

PUSEY, B.J., ARTHINGTON, A.H. and READ, M.G. The dry-season diet of freshwater fishes in monsoonal tropical rivers of Cape York Peninsula, Australia. Ecology Freshwater Fish, 2000, 9(3), 177-190. http:// dx.doi.org/10.1111/j.1600-0633.2000.eff090307.x.

RODAL, M.J.N., ANDRADE, K.V.A., SALES, M.F. and GOMES, A.P.S. Fitossociologia do componente lenhoso de um refúgio vegetacional no município de Buique, Pernambuco. Revista Brasileira de Biologia, 1998, 58(3), 517-526. http://dx.doi.org/10.1590/ S0034-71081998000300017.

ROSA, R.S., MENEZES, N.A., BRITSKI, H.A., COSTA, W.J.E.M. and GROTH, F. Diversidade, padrôes de distribuição e conservaçáo dos peixes da Caatinga. In I.R. LEAL, J.M.C. SILVA and M. TABARELLI, eds. Ecologia e conservação da Caatinga. Recife: EDUFPE, 2003, pp. 135-181.

ROSS, S.T. Mechanisms structuring stream fish assemblage: are there lessons from introduced species? Environmental Biology of Fishes, 1991, 30(4), 359368. http://dx.doi.org/10.1007/BF02027979.

ROUGHGARDEN, J. and FELDMAN, M. Species packing and predation pressure. Ecology, 1975, 56(2), 489-492. http://dx.doi.org/10.2307/1934982.

SEGERS, H. Annotated checklist of the rotifers (Phylum Rotifera), with notes on nomenclature, taxonomy and distribution. Zootaxa, 2007, 1564, 1-104.

SILVA, M.J., FIGUEIREDO, B.R.S., RAMOS, R.T.C. and MEDEIROS, E.S.F. Food resources used by three species of fish in the semi-arid region of Brazil.
Neotropical Ichthyology, 2010, 8(4), 819-825. http:// dx.doi.org/10.1590/S1679-62252010005000010.

SUÁREZ, E., REID, J.W., ILIGE, T.M. and FIERS, F. Catálogo de los copépodos (Crustácea) continentales de la peninsula de Yucatán, México. Mexico: ECOSUR/ CONABIO, 1996, 296 p.

TABARELLI, M. and SILVA, J.M.C. Áreas e açóes prioritárias para a conservação da biodiversidade da Caatinga. In I.R. LEAL, J.M.C. SILVA, and M. TABARELLI, eds. Ecologia e conservação da Caatinga. Recife: EDUFPE, 2005, pp. 777-796.

TOGUYENI, A., FAUCONNEAU, B., BOUJARD, T., FOSTIER, A., KUHN, E.R., MOL, K.A. and BAROILLER, J.F. Feeding behaviour and food utilisation in tilapia, Oreochromis niloticus: effect of sex ratio and relationship with the endocrine status. Physiology \& Behavior, 1997, 62(2), 273-279. http://dx.doi.org/10.1016/S0031-9384(97)00114-5. PMid:9251968

WILLIAMS, D.D. and FELTMATE, B.W. Aquatic insects. Oxon: CAB International, 1992, 358 p.

WIMBERGER, P.H. Plasticity of jaw and skull morphology in the neotropical cichlids Geophagus brasiliensis and G. steindachneri. Evolution; International Journal of Organic Evolution, 1991, 45(7), 1545-1563. http://dx.doi.org/10.2307/2409778.

WINEMILLER, K.O. and PIANKA, E.R. Organization in natural assemblages of desert lizards and tropical fishes. Ecological Monographs, 1990, 60(1), 27-55. http://dx.doi.org/10.2307/1943025.

WOOTTON, R.J. Ecology of teleost fishes. London: Chapman \& Hall, 1990, 404 p.

ZARET, T.M. and RAND, A.S. Competition in tropical stream fishes: support for the competitive exclusion principle. Ecology, 1971, 52(2), 336-342. http:// dx.doi.org/10.2307/1934593.

Received: 05 May 2014 Accepted: 29 January 2015 